\title{
Paper 9
}

\section{Homing of Black Bears in the Great Smoky Mountains National Park}

\author{
LARRY E. BEEMAN* AND MICHAEL R. PELTON \\ Department of Forestry, University of Tennessee, Knoxville, Tennessee 37916.
}

\section{INTRODUCTION}

The interactions between nuisance black bears (Ursus americanus) and people create many problems in the Great Smoky Mountains National Park (GSMNP or Park) as well as in other areas of North America. These interactions necessitate management guidelines determined from biological data about the bears. Personnel of the National Park Service (NPS) have handled nuisance bears by moving them to various areas within the Park, transporting them to state wildlife management areas or in some instances destroying habitually muisance animals. Generally, bears have been destroyed only when other management procedures failed and the animal was judged to present a potential danger to Park visitors.

Eliminating the causal factors that create nuisance bears is the most effective and economical method of reducing the number of bear-people interactions. Park personnel have attempted to do this by transporting roadside and campground garbage to landfills outside the Park. Feeding of bears is prohibited in the Park. 'Regular' garbage cans are being replaced by 'bearproof' ones. Back-packers must pack all trash and garbage out of the backcountry. Although these precautionary measures have alleviated some of the problem, they have not been completely effective and some unnatural sources of food are still available thus creating nuisance bears.

Once a bear has 'established' itself as a nuisance animal, removing if from the area of nuisance is the most humane method of handling it; this procedure presents problems. The limited size of the GSMNP (approximately 32 by 70 kilometers) introduces the question of whether the Park is large enough for this management practice. The limited road system within the Park hinders the transplant of bears into more remote areas (Fig. 1). Capturing nuisance animals and moving them into remote areas is time consuming and limited by the availability of manpower. Most of the areas surrounding the Park have a high human population density with no buffer zone between the Park and areas inhabited by people.

This research investigated one aspect of the problem of handling nuisance bears, that of homing. The ability of an animal to return to its homesite has been reported in birds (Bellrose 1958; Sauer and Sauer 1960), dogs (Canis domesticus) (Carthy 1956:183), gray squirrels (Sciurus carolinensis) (Hunger-

\footnotetext{
* Present address: Division of Forestry, Fisheries and Wildlife Development, Tennessee Valley Authority, Norris, Tennessee.
} 


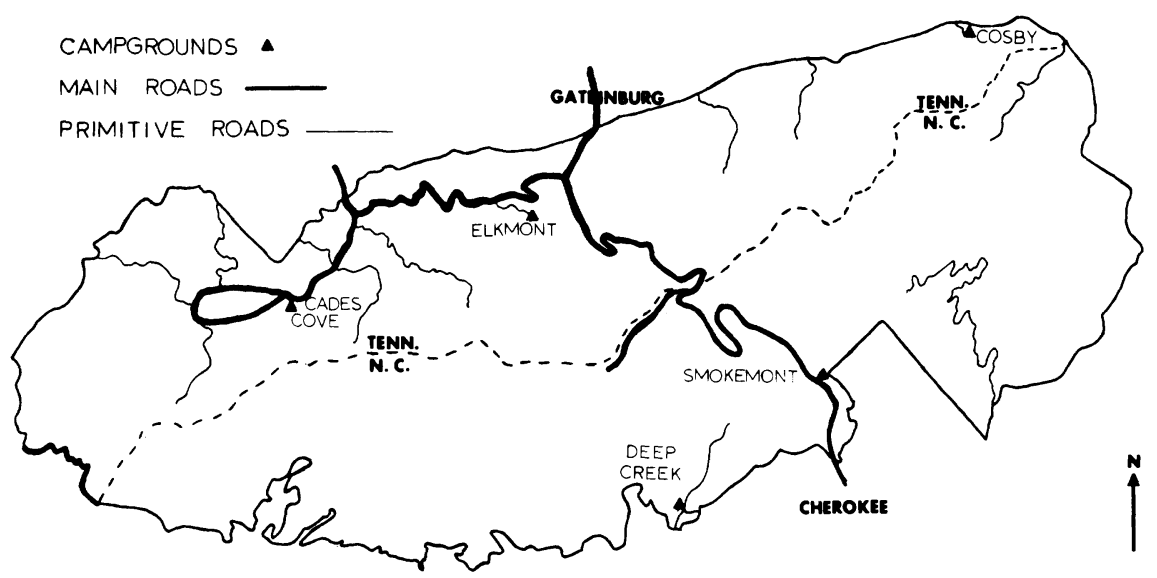

Fig. 1. A map of the Great Smoky Mountains National Park showing areas of black bear nuisance (campgrounds and main roads) and the limited number of primitive roads allowing access into more remote sections of the Park.

ford and Wilder 1941) and mice (Peromyscus spp.) (Griffo 1961; Bovet 1968; Furrer 1974).

Wasem (1968) reported that 8 of 13 (62 percent) habitual nuisance bears in Glacier National Park homed. In Michigan, Erickson (1964) transplanted 17 black bears an average of 63 kilometers and considered only two of these to have homed. One of these was an adult male that was killed within 9.7 kilometers of the capture point after being moved 151.6 kilometers. The other was an adult female captured 30.6 kilometers from the original capture point after being moved 103.2 milometers. Of the transplanted bears, Erickson concluded that males moved greater distances than females and adults farther than juveniles. Harger (1967) found a definite tendency for transplanted black bears to move toward the original point of capture. Of the 18 bears furnishing movement records, Harger considered that 12 individuals had homed, with cubs exhibiting poorer homing ability than older bears. Sauer et al. (1969) transplanted 52 nuisance black bears 13.9 to 106.6 kilometers and found 43 percent were able to home. They concluded that homing fell off sharply when bears were transplanted more than 64 kilometers from their capture point. Other than these studies (many of which present limited sample sizes), there is little available literature that statistically quantifies the homing ability of black bears.

Since the study area was in the GSMNP where over 8,000,000 people visit annually, the researchers were required to trap and relocate bears as deemed necessary by NPS personnel. The NPS supervised the relocation of nuisance animals; this altered the experimental design and limited the interpretation of some of the results.

\section{METHODS}

Bears that habitually entered campgrounds or roadsides and were judged bold enough to cause damage or injury to Park visitors and their equipment were considered nuisance animals. These animals were captured with culvert traps and Aldrich snares or immobilized while free-roaming with Etrophine (M99) 
or Sernylan injected with a syringe rifle. Bears were then transported to the release site in a culvert trap. Individuals were ear tagged with cattle Rototags (Nasco Co., Fort Atkinson, Nebraska) using various color combinations so individuals could be identified without recapturing. A bear was considered to have homed if it returned to within 8 kilometers of the original capture point. In every case but two, bears that homed in this study returned to within 2 kilometers of the original capture point. Individual bears were identified by members of the research team. At times, employees of the GSMNP and repeated reports of individually-marked bears by Park visitors were helpful in identification.

Age of most bears was determined by the cementum-annuli (Willey 1974). When a tooth was not extracted, age was estimated by comparative body size and dental wear. For this study bears 4.5 years old were considered 'adults' and bears less than 4.5 years old were considered 'juveniles.' No cubs and only one yearling were moved as a nuisance animal. Thus, with one exception, the juvenile group in this study is subadults 2.5 and 3.5 years old.

Inexperienced bears are defined as individuals trapped and transplanted for the first time. Experienced individuals are bears trapped two or more times and transplanted. The time of homing was calculated from the date of release

Table 1. Transplant of nuisance female bears (adults) in the GSMNP, $1967-1974$.

\begin{tabular}{|c|c|c|c|}
\hline Date & $\begin{array}{l}\text { Bear } \\
\text { Number }\end{array}$ & $\begin{array}{l}\text { Displacement } \\
(\mathrm{km})\end{array}$ & Comments \\
\hline $6 / 15 / 67$ & 1 & 46.4 & Never reobserved \\
\hline $7 / 16 / 67$ & 2 & 16 & Never reobserved \\
\hline $7 / 27 / 67$ & 3 & Not recorded & Given to North Carolina \\
\hline $8 / 11 / 67$ & 4 & Not recorded & Given to North Carolina \\
\hline $6 / 1 / 68$ & 5 & 9.6 & $\begin{array}{l}\text { Homed in } 15 \text { days: recap- } \\
\text { tured } 6 / 16 / 68\end{array}$ \\
\hline $6 / 16 / 68$ & 5 & Not recorded & Given to North Carolina \\
\hline $7 / 2 / 68$ & 6 & 7.2 & $\begin{array}{l}\text { Homed in } 31 \text { days: recap- } \\
\text { tured } 8 / 2 / 68\end{array}$ \\
\hline $8 / 2 / 68$ & 6 & 7.2 & Never reobserved \\
\hline $9 / 9 / 70$ & 7 & 19 & $\begin{array}{l}\text { Homed the following spring; } \\
\text { recaptured } 5 / 23 / 71\end{array}$ \\
\hline $5 / 23 / 71$ & 7 & 19 & $\begin{array}{l}\text { Reobserved and captured } \\
8 / 30 / 71 \text { at original capture } \\
\text { point }\end{array}$ \\
\hline $8 / 30 / 71$ & 7 & 19 & Never reobserved \\
\hline $7 / 28 / 72$ & 8 & 24.8 & Never reobserved \\
\hline $8 / 11 / 72$ & 9 & 58 & Never reobserved \\
\hline $11 / 14 / 72$ & 10 & 28 & Never reobserved \\
\hline
\end{tabular}


to the date of first observation or recapture within 8 kilometers of the original capture point. The recorded time period is the minimum time of homing since bears could have returned without being trapped or seen until a later date.

Distance between two locations within the Park is given in air-kilometers and, therefore, due to the mountainous terrain is less than the actual minimum distance.

Chi-square contingency tables, Fisher Exact Probability Test and Student's t-test were used to test for statistical significance. Levels of significance were set at $\mathrm{P}<.10$ since tendencies rather than absolute differences between bears were being measured.

\section{RESULTS AND DISCUSSION}

\section{Males versus females}

From 1967 to 1974,76 nuisance bears were captured and displaced a total of 155 times. Individual bears were captured one to 13 times and were displaced an average of 21.7 air-kilometers (range 5.8 to 64.8 kilometers). Males comprised 87 percent of the nuisance bears and juveniles (all males) 20 per cent. All females were adults and only one (10 percent) was recorded as having cubs (Table 1).

The predominance of males classified as nuisance bears is in general agreement with Erickson (1964), Harger (1967), Wasem (1968), and Sauer et al. (1969), who reported between 71 and 80 percent males. Although the sample size of females is small $(n=10)$, the results suggest that females having young may be more wary of people and less likely to enter campgrounds and roadsides. Since females have the potential to give birth to young in aiternate years and yearlings remain with the sow for a period of time into the summer, this may have a 'dampening' effect on females establishing a garbage-seeking hehavior.

The greatest homing distance in the GSMNP was an adult male returning 64 kilometers. The greatest homing distance of the three females that homed was 19 kilometers (Table 1 ).

There was no significant difference $(P=22)$ between the homing ability of inexperienced females ( 30 percent) and inexperienced males ( 50 percent) (Table 2). Differences between experienced maies and females was not tested statistically due to the limited sample size of females (Table 1).

Approximately 33 percent of the inexperienced juvenile males $(n=15)$ and 55 percent of the inexperienced adult males $(n=51)$ homed. However, these differences were not significant $(.20 \geqslant P \geqslant .10)$. As previously mentioned, none of the juveniles were cubs and only one bear was judged to be a yearling. Therefore, it would be more precise to state that no statistical difference was found between subadults (2.5 and 3.5 years old) and adult bears.

\section{Distance transplanted and homing}

There was a tendency for bears transplanted farther from their capture point to have a lower probability of homing. The females that homed $(n=3)$ were displaced an average of 11.9 kilometers (range 7.2 to 19 kilometers) and the females not known to home $(n=7)$ were transplanted an average of 35.6 kilometers (range 16 to 58 kilometers) (Table 1). Approximately 54 percent $(\mathrm{n}=56)$ of the male bears displaced less than 30 kilometers homed (Table 2). 
Paper $9 \quad 91$

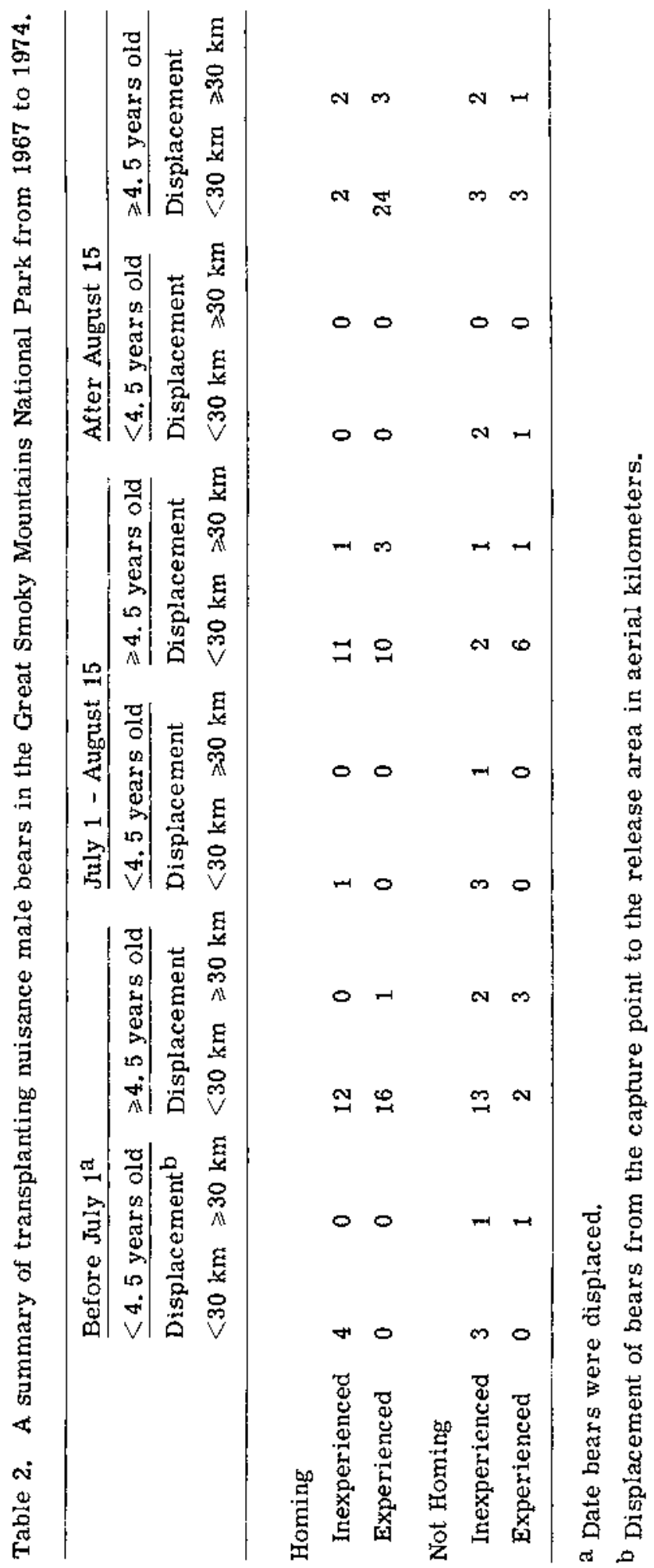


The probability of distance causing a difference in homing ability $(P=.08)$ was significant.

The total area in the GSMNP $\left(2072 \mathrm{~km}^{2}\right)$ is relatively small for animals as mobile and wide-ranging as black bears (Erickson 1964; Harger 1967; Sauer et al. 1969). However, the Park has rugged topography typified by narrow valleys and steep slopes creating rapid elevation changes ranging from 275 to $2,200 \mathrm{~m}$. This rough topography combined with thick vegetation may hinder long movements of bears within the Park.

\section{Experienced versus inexperienced bears}

There was a significant difference $(0.1 \geqslant P \geqslant .05)$ between the homing capabilities of experienced (includes second capture only) and inexperienced male bears $\left(X^{2}=3.2,1\right.$ d.f. $)$. Fifty percent of the inexperienced males $(n=66)$ homed and 70 percent of the bears transplanted for the second time homed. Bears transplanted after August 15 were excluded from these analyses since there may have been inadequate time for reobservation before the denning period. Data on female bears were inadequate for statistical analysis.

The average homing rate for experienced male bears transplanted the second time was 0.51 kilometers/day. Inexperienced male bears that homed averaged 179.5 days to return for an average rate of 0.17 kilometers/day. Nine of these bears were not reobserved at their capture point until the following summer. Bears homing the second time did so in statistically significant less time $(.10$ $\geqslant P \geqslant .05$ ) than bears homing the first time.

\section{Comparison of release areas}

Poaching is an important factor influencing the homing of displaced bears in the Park. Records of the NPS and the Tennessee Wildlife Resources Agency indicate heavy hunting along the periphery of the Park. To test the hypothesis that bears released along the periphery are less likely to return than animals released at more centrally located release sites, a comparison was made between two release points. One release point, Tremont, is centrally located within the Park and is not easily accessible to anyone except Park personnel (Fig. 1). The other area, Parson's Branch Road, is near the border of the Park and also near a major U.S. Highway (US 129). Tremont is 19 air-kilometers from Cades Cove. While Parson's Road is 4 kilometers farther away from the capture point than Tremont, the difference is assumed to be negligible.

It was found that bears released at Tremont homed 86 percent of the time $(\mathrm{n}=18)$ while only 56 percent of the animals released at Parson's Branch homed $(n=16)$. These differences were significant $(P=.09)$.

Habitat and terrain differences were not evaluated but could have affected homing incidence along with poaching. In addition to poaching, the lack of a buffer zone between the Park and outlying areas should be considered when relocating bears.

\section{Orientation}

Besides indicating that experienced bears are more likely to home and home in less time, our data suggest that bears are either capable of learning and memory of terrain outside their home range, and/or previous homing experience increases their efficiency of homing. Motivation is another aspect of homing. Griffo (1961) stated home range may not only satisfy the physical 
needs which might often be provided equally well or better in other areas, but may also provide a psychic function. This psychic function may allow bears to move about areas with which they are familiar with assurance and to efficiently utilize the resources with which they are intimately attached. Also, whatever intraspecific social relationship was present may be altered when bears are moved to unfamiliar areas. Territoriality, if existent, would also be affected. These factors may motivate bears that have been artificially transplanted to seek their original homesite. Many of the animals transplanted were released in areas near sources of garbage (campgrounds, shelters, etc.). Of those bears transplanted only one (1.3 percent) became a nuisance animal in an area other than near the original capture point. This presents additional evidence that bears were not inclined to remain in unfamiliar areas outside their home range and were motivated to return home. Since bears are highly mobile, evidently motivated to return to their homesite, and capable of learning and memory, they are thus quite successful in returning to their original homesite.

If we accept that bears possess a homing ability and for one reason or another are motivated to return to their established home range, the question arises as to how bears are capable of relocating this area after being transplanted. Griffo (1961), Furrer (1973) and others have postulated that small rodents homed by randomly wandering in unfamiliar terrain until familiar terrain is encountered and nonrandom movements in terrain with which the animal has some previous familiarity.

It is reasonable to assume that bears are familiar with their home range. However, it is known that animals occasionally make excursions out of their home range. In Burt's (1943) classical definition of home range, he includes the idea of an animal's occasional excursion outside its normal home range. Also, it is a well accepted observation that many young animals disperse from their birthplace to unfamiliar areas to establish a homesite. In the GSMNP there is evidence of extensive wanderings by yearling and subadult bears (Beeman, unpublished data). The movements of animals beyond their established home range allows an opportunity for bears to familiarize themselves with terrain beyond their home range. Furrer (1973) and others have employed the term life range for including the total area an animal has traversed during its lifetime. A life range may have little biological significance for normal day to day activities, but could be important in a bear's ability to orient itself after being artificially displaced.

The above discussion introduces the question of how well bears can learn features of the terrain and their ability to retain a memory of such features for long periods of time. In testing for color and form discrimination by black bears, Bacon (1973) concluded that bears can make rapid visual discrimination and can remember a task for long periods of time. He also stated that their retention ability may be related to their high degree of persistence.

While much of the evidence presented in this study is circumstantial, experienced bears were more likely to home and homed in less time than inexperienced bears. It, therefore, appears that learning and memory of the terrain encountered do play a role in homing ability.

Orientation other than by previous association with the terrain is also possible. For example, polar bears (U. maritimus) would be unable to return to areas previously visited while living on drifting ice which changes form and carries them elsewhere, if they were not somehow able to navigate (Lentfer, personal comment). However, other means of orientation were not tested in this study. 


\section{Management implications}

Creating conditions to reduce unnatural food available to bears is probably the most important management tool for reducing the number of nuisance animals. Eliminating all sources of unnatural food is not realistic in the GSMNP (or any other park) so the problem of nuisance bears will not be totally eliminated. Another precautionary step is to move a bear as soon as possible after it enters a campground or roadside and thus reduce the amount (frequency) of reinforcement (food) that a particular animal receives.

Since 50 percent of the male and 70 percent of the female bears transplanted for the first time did not home, the first transplant may be important in eliminating future encounters with a particular animal. Although this study only provided limited data to evaluate how well inexperienced bears will home from transplants over 50 kilometers $(n=3)$, distance appears to be an impor tant parameter of homing. While it may require much time to move a bear the first time to an appropriate area, it likely reduces the chances of having to handle that particular bear again.

The relatively small area of the Park may prove to be inadequate to successfully transplant bears captured in some areas. There are a limited number of places within the Park that are less than 10 kilometers from a source of unnatural food (campgrounds, roadsides, or backcountry shelters). Yet, only one out of 76 bears transplanted was reported to have caused a nuisance other than at the original capture point. Our data indicate that the probability of a bear becoming a nuisance other than in its established home range is quite low; this should be considered when determining possible locations for transplanting bears. Thus, an area for relocating a bear does not necessarily need to be eliminated as a choice because of its proximity to another campground, roadside, etc.

Poaching may be an important factor when selecting a release site in the GSMNP. While moving bears to a peripheral area of the Park may eliminate a nuisance problem, it may do so at the cost of the bear. This difficulty is magnified by the lack of any buffer zone around most of the Park's periphery and the proximity of areas of relatively dense populations of people.

\section{SUMMARY}

From 1967 to 1974,76 nuisance black bears were moved to other parts of the Park. Most nuisance bears were males (87 percent). Bears less than 4.5 years old comprised 20 percent of the nuisance animals. There was no significant difference between the ability of inexperienced adults and inexperienced juveniles to home. Within the range of distances that bears were moved ( 5.8 to $64.8 \mathrm{~km}$ ), there was a significant difference between homing and distance transplanted, i.e. fewer homing with greater distances moved.

Experienced male bears were significantly more likely to home and homed in less time than inexperienced males. Bears released on the periphery of the Park were significantly less likely to home than bears released in the central part of the Park.

Bears seem to be strongly motivated to home. A bear's home range probably provides psychic needs as well as physical ones. They likely find their way by random wanderings combined with learning and memory of areas previously traversed. Other means of navigation were not tested in this study.

Creating conditions that reduce the amount of unnatural food available to bears is probably the most basic management tool for eliminating the transformation 
of 'wild' bears to nuisance animals. Selection of release sites is also an important consideration in handling muisance bears.

\section{ACKNOWLEDGEMENTS}

Financial support for this project was made available through funds from the Great Smoky Mountains Natural History Association and McIntire-Stennis Project No. 12 of the Department of Forestry, the University of Tennessee. The National Park Source and personnel of the Great Smoky National Park are recognized for their encouragement, help and cooperation during the study.

\section{REFERENCES}

BACON, E. S. 1973. Investigation on perception and behavior of the American Black Bear (Ursus americanus). Unpublished Ph. D. thesis, Univ. of Tennessee, Knoxville, $161 \mathrm{pp}$.

BELLROSE, F.C. 1958. The orientation of displaced waterfowl in migration. Wilson Bull. 70: 20-40.

BOVET, J. 1968. Tracks of deer mice (Peromyscus maniculatus) travelling on the snow while homing. J.Mamm. 49: 713-725.

BURT, W. H. 1943. Territoriality and home range concepts as applied to mammals. J.Mamm. 24: 346-352.

CARTHY, J. D. 1956. Animal navigation. Charles Scribner's Sons, New York, $151 \mathrm{pp}$.

ERICKSON, A. W. 1964. Breeding biology and ecology of the black bear. Unpublished Ph. D. thesis, Michigan State University, Ann Arbor, 311 pp.

FURRER, R. K. 1973. Homing of Peromyscus maniculatus in channeled scablands of east-central Washington. J.Mamm. 54: 466-482.

GRIFFO, J. V. 1961. A study of homing in the cotton mouse, Peromyscus gossypinus. Amer. Midland Nat. 65: 257-289.

HARGER, E. M. 1967. Homing behavior of black bears. Michigan Dept. of Cons. Res. and Develop. rpt. 118, 12 pp.

HUNGERFORD, K. E. and WILDER, N. G. 1941. Observations on the homing behavior of the gray squirrel (Sciurus carolinensis). J. Wildl. Mgmt. 5: $458-460$.

SAUER, E. G. F. and SAUER, E. 1960. Star navigation of nocturnal migrating birds. Cold Spring Harbor Symp. Quant. Biol. 25: 463-473.

SAUER, P. R., FREE, S. L. and BROWNE, S. D. 1969. Movement of tagged bears in the Adirondacks. N. Y. Fish and Game Jour. 16: 205-223.

WASEM, C. R. 1968. Movement and management of marked black bears in Glacier National Park. National Park Service Report, January 15, 1968, $12 \mathrm{pp}$.

WILLEY, C. H. 1974. Aging black bears from first premolar tooth sections. J. Wildl. Mgmt. 38: 97-100. 